\title{
Direct-acting antivirals and visceral leishmaniasis: a case report
}

\author{
Claudia Colomba*, Laura Saporito, Paola Di Carlo, Manlio Tolomeo, Adriana Cervo, Alberto Firenze, \\ Marcello Trizzino and Antonio Cascio
}

\begin{abstract}
Background: Visceral leishmaniasis is a vector-borne parasitic disease caused by protozoa belonging to the genus Leishmania. The clinical presentation of visceral leishmaniasis strictly depends on the host immunocompetency, whereas depressive conditions of the immune system impair the capability to resolve the infection and allow reactivation from sites of latency of the parasite.

Case presentation: We describe a case of visceral leishmaniasis $(V L)$ that occurred in a patient with chronic hepatitis $C$ treated with direct-acting antiviral drugs (DAA). The hypothesized mechanism is the alteration of protective inflammation mechanisms secondary to DAA therapy. Downregulation of type II and III IFNs, their receptors, which accompany HCV clearance achieved during treatment with sofosbuvir and ribavirin might have a negative impact on a risk for reactivation of a previous Leishmania infection. We know indeed that IFN- $\gamma$ is important to enhance killing mechanisms in macrophages, which are the primary target cells of Leishmania.

Conclusion: Since VL is endemic in Sicily as well as in other countries of the Mediterranean basin, physicians should be aware of the possible unmasking of cryptic Leishmania infection by DAAs.
\end{abstract}

Keywords: Hepatitis C, Leishmania, Visceral Leishmaniasis, Direct-acting antiviral

\section{Background}

Visceral leishmaniasis (VL) is a vector-borne parasitic disease caused by protozoa belonging to the genus Leishmania. The clinical presentation of visceral leishmaniasis strictly depends on the host immunocompetency and ranges from asymptomatic to severe forms characterized by fever, splenomegaly and pancytopenia. Depressive conditions of the immune system such as HIV infection, immunosuppressive treatments, and cirrhosis impair the capability of the immune response to resolve the infection and allow reactivation from sites of latency of the parasite [1-4]. VL has also been reported during pegylated interferon therapy for chronic hepatitis $C$ [5]. Over 70 million people worldwide are chronically infected with hepatitis $\mathrm{C}$ virus (HCV) and it is estimated that in Sicily there is a burden of at least $150,000 \mathrm{HCV}$ infected patients: since 2015 almost 10,000 patients were treated with direct-acting antiviral agents (DAA) [6]. IFN-free

\footnotetext{
* Correspondence: claudia.colomba@libero.it

Dipartimento di Scienze per la promozione della Salute e Materno-infantile, Università di Palermo, Palermo, Italy
}

DAA combination therapies for $\mathrm{HCV}$ are oral regimens that are well tolerated, and typically induce rapid and sustained viral response (SVR) [7]. Anyway the effect of DAA on the incidence of other infections in clinical practice is still unclear. We describe here a case of $\mathrm{VL}$ that occurred in a patient with chronic hepatitis $\mathrm{C}$ treated with DAA.

\section{Case presentation}

A Sicilian seventy-year-old man was admitted to the Infectious Diseases Unit of the University Hospital of Palermo (Sicily, Italy) in July 2017 referring progressive asthenia and irregular fever not responsive to antibiotic therapy lasting 2 months. The patient suffered from diabetes mellitus, mild kidney disease, and $\mathrm{HCV}$-related liver cirrhosis (Child-Pugh B7), for which had been treated with sofosbuvir and ledipasvir for 24 weeks until December 2015.

About 3 months later the end of the HCV-treatment, the patient suffered from a marked worsening of thrombocytopenia, not considered related to liver cirrhosis and not responding to steroid therapy for which 
he had been treated with romiplostim whenever platelet count was under $20,000 / \mathrm{mmc}$.

At admission in our division, the patient had fever (BT $37.8^{\circ}$ ) with a pulse rate of $78 \mathrm{bpm}$, blood pressure and respiratory rate were normal. No other symptoms were reported except asthenia. At the physical examination he had no respiratory alterations, systolic heart murmur at apex (grade II/VI), hepatosplenomegaly and grade 1-encephalopathy with bradilalia and minimal flapping tremor.

Laboratory tests revealed pancitopenia (WBC 3100/ mmc -neutrophils 46\%, lymphocytes 33\%-, Hb $8.1 \mathrm{~g} / \mathrm{dl}$, platelets $46,000 / \mathrm{mmc}$ ), an increased C-reactive protein (33 mg/l), D-dimer $6980 \mathrm{UI} / \mathrm{l}$ and INR 1.5, eGFR $63 \mathrm{ml} /$ $\mathrm{min} / 1.73 \mathrm{~m}^{2}$, AST/ALT $2 \mathrm{xN}$, modest hypoalbuminemia with polyclonal gammopathy.

The abdominal ultrasound exam showed an increase in splenomegaly $(17 \mathrm{~cm})$ compared to the previous ultrasonography from 1 month earlier $(14.5 \mathrm{~cm})$. Thoracic CT scanning was normal. Trans-thoracic echocardiography excluded vegetations. Blood culture, brucellosis serology, HIV-IgG and HBsAg were negative. Leishmania serology resulted positive in enzyme-linked-immunosorbent-assay (IgG 1:12800), immunofluorescent antibody test (IgG 1:25600) performed as previously described [2] (Table 1) and Western Blot.

Leishmania infantum DNA was detected in peripheral blood by Real-time Polymerase Chain Reaction (PCR) targeted on a $117 \mathrm{bp}$ fragment in the mini circle kinetoplast DNA (kDNA), carried out as previously described by Vitale et al. [8].

A bone marrow aspirate was not performed because of low platelet count. Liposomal amphotericin B was started at the dose of $3 \mathrm{mg} / \mathrm{kg}$ from day 1 to 5 and a further dose on day 10 for a total dose of $18 \mathrm{mg} / \mathrm{kg}$.

The blood cells count and the clinical conditions of the patient progressively improved until reaching normal values; L. infantum real-time PCR on peripheral blood at the end of the treatment was negative.

\section{Discussion and conclusions}

It is well known that T-cell-dependent immune response and macrophage activation play a major role during primary Leishmania infection or reactivation of latent infection, in addition the effect of DAA on the host immune status has also recently been addressed $[1,7]$. It

Table 1 Serological tests indicating L. infantum infection

\begin{tabular}{lll}
\hline L. infantum diagnostic test & $\begin{array}{l}\text { Positivity } \\
\text { threshold }\end{array}$ & $\begin{array}{l}\text { Patient's } \\
\text { value }\end{array}$ \\
\hline $\begin{array}{l}\text { Enzyme-linked-immunosorbent-assay } \\
\text { (ELISA) (lgG) }\end{array}$ & $1: 50$ & $1: 12800$ \\
$\begin{array}{l}\text { Immunofluorescent antibody test } \\
\text { (IFAT) (IgG) }\end{array}$ & $1: 50$ & $1: 25600$ \\
\hline
\end{tabular}

has been well documented that DAA regimens are associated to lower side-effects and higher rate of SVR obtained in a shorter time frame than interferon and ribavirin. However, some researchers are now discovering an increased rate of de novo and recurrent hepatocellular carcinoma (HCC) in patients with HCV cirrhosis compared to interferon treatment protocols. The hypothesized mechanisms is that inflammation secondary to chronic $\mathrm{HCV}$ infection plays a role in immunosurveillance. DAA therapy seems to abolish this protective and antineoplastic effect [9]. Moreover, Meissner et al. demonstrated that treatment with sofosbuvir and ribavirin is associated to downregulation of type II and III IFNs, their receptors and interferon stimulated genes in liver [10]. This might have a negative impact on immune control allowing reactivation of a previous infection. HBV reactivation occurs frequently in patients with chronic $\mathrm{HBV}$ and $\mathrm{HCV}$ coinfection receiving DAA therapy. It is therefore important to have all patients screened for evidence of overt or occult HBV infection and properly manage the coinfection during DAAs therapy [11].

We know that IFN- $\gamma$ is important to enhance killing mechanisms in macrophages, which are the primary target cells of Leishmania as well as other intracellular infections such as tuberculosis. Consequently, a potential risk for reactivation of a previous Leishmania or Mycobacterium tuberculosis infection during DAA therapy is possible [12]. Since VL is endemic in Sicily as well as in other countries of the Mediterranean basin, and physicians should be aware of the possible unmasking of cryptic Leishmania infection after DAAs therapy. Even if this risk is not considered as a contraindication for anti-HCV treatment, baseline screening could be suggested when this treatment is started in these epidemiological settings.

\section{Abbreviations}

bpm: beats per minute; $\mathrm{BT}$ : Body temperature; $\mathrm{CT}$ : Computed tomography; DAA: Direct-Acting Antiviral; eGFR: estimated glomerular filtration rate; Hb: Haemoglobin; HBV: Hepatitis B Virus; HCV: Hepatitis C Virus; HIV: Human Immunodeficiency Virus; IFN: Interferon; PCR: Polymerase chain reaction; VL: Visceral leishmaniasis; WBC: White blood cells

\section{Acknowledgements}

We have not received substantial contributions from non-authors.

\section{Funding}

This report received no specific grant from any funding agency in the public, commercial, or not-for-profit sectors.

\section{Availability of data and materials}

The datasets used and analyzed during the current study are available from the corresponding author on reasonable request.

\section{Authors' contributions}

CC, SL, and CA developed the idea of the study, participated in its design and coordination and helped to draft the manuscript. DCP, FA and ToM contributed to the acquisition and interpretation of data. CC, TrM and CA were involved in critically reviewing data for important intellectual content. All authors read and approved the final manuscript. 
Ethics approval and consent to participate

Not applicable.

\section{Consent to publish}

Written informed consent was obtained from the patient for publication of this case report. A copy of the written consent is available for review by the Editor of this journal.

\section{Competing interests}

The authors declare that they have no competing interests.

\section{Publisher's Note}

Springer Nature remains neutral with regard to jurisdictional claims in published maps and institutional affiliations.

Received: 14 July 2018 Accepted: 3 April 2019

Published online: 18 April 2019

\section{References}

1. Saporito L, Giammanco GM, De Grazia S, et al. Visceral leishmaniasis: hostparasite interactions and clinical presentation in the immunocompetent and in the immunocompromised host. Int J Infect Dis. 2013;17:572-6.

2. Colomba C, Saporito L, Vitale F, Reale S, Vitale G, Casuccio A, Tolomeo M, Maranto D, Rubino R, Di Carlo P, Titone L. Cryptic Leishmania infantum infection in Italian HIV infected patients. BMC Infect Dis. 2009;9:199. https:// doi.org/10.1186/1471-2334-9-199.

3. Pagliano P, Esposito S. Visceral leishmaniosis in immunocompromised host: an update and literature review. J Chemother. 2017;29:261-6.

4. Puoti M, Babudieri S, Rezza G, et al. Use of pegylated interferons is associated with an increased incidence of infections during combination treatment of chronic hepatitis C: a side effect of pegylation? Antivir Ther. 2004;9:627-30.

5. Cascio A, Antinori S, Ricciardi F, Costantino G, laria C. Visceral leishmaniasis during pegylated interferon therapy for chronic hepatitis C: first report. Antivir Ther. 2005;10:695-6; author reply 696.

6. F C, Di Marco V, RESIST - HCV. The HCV Sicily network: a web-based model for the management of HCV chronic liver diseases. Eur Rev Med Pharmacol Sci. 2016;20(1 Suppl):11-6.

7. Shah N, Pierce T, Kowdley KV. Review of direct acting antiviral agents for the treatment of chronic hepatitis C. Expert Opin Investig Drugs. 2013;22:1107-21.

8. Vitale F, Reale S, Vitale M, Petrotta E, Torina A, Caracappa S. TaqMan-based detection of Leishmania infantum DNA using canine samples. Ann N Y Acad Sci. 2004 Oct;1026:139-43.

9. Grandhe S, Frenette $C T$. Occurrence and recurrence of hepatocellular carcinoma after successful direct-acting antiviral therapy for patients with chronic hepatitis C virus infection. Gastroenterol Hepatol (N Y). 2017;13:421-5.

10. Meissner EG, Wu D, Osinusi A, et al. Endogenous intrahepatic IFNs and association with IFN-free HCV treatment outcome. J Clin Invest. 2014; 124:3352-63.

11. Mücke $M$, Backus $L I$, Mücke VT, et al. Hepatitis B virus reactivation during direct-acting antiviral therapy for hepatitis C: a systematic review and metaanalysis. Lancet Gastroenterol Hepatol. 2018;3:172-80.

12. Ballester-Ferré MP, Martínez F, Garcia-Gimeno N, Mora F, Serra MA. Miliary tuberculosis infection during hepatitis $C$ treatment with sofosbuvir and ledipasvir plus ribavirin. World J Hepatol. 2017;9:161-6.

Ready to submit your research? Choose BMC and benefit from:

- fast, convenient online submission

- thorough peer review by experienced researchers in your field

- rapid publication on acceptance

- support for research data, including large and complex data types

- gold Open Access which fosters wider collaboration and increased citations

- maximum visibility for your research: over $100 \mathrm{M}$ website views per year

At BMC, research is always in progress.

Learn more biomedcentral.com/submissions 